\title{
International efforts to create a weapons of mass destruction free zone in the Middle East
}

\author{
NAGY Milada ${ }^{1}$
}

\begin{abstract}
The efforts to create a nuclear weapons - later weapons of mass destruction ${ }^{2}$
- free zone in the Middle East face many difficulties: the Arab-Israeli conflict, the deterioration of the Israeli-Palestinian peace process, the growing number of actors in the peace process, the nuclear program of Iran, the security policy of Israel etc. The aim of this paper is to give an overview of the international (United Nations [UN], European Union [EU]) efforts from the 1960s to the indefinite post-ponement of the Middle East weapons of mass destruction free zone (MEWMDFZ) conference planned for December 2012.

Keywords: Middle East, weapons of mass destruction free zone, United Nations, NPT 1995 resolution, European Union
\end{abstract}

\section{The beginnings}

Efforts to create nuclear-weapons-free zones (NWFZ) are not new, their origin dates back to the 1960s. One of the cornerstones of the nonproliferation regime of the nuclear weapons is the Nuclear Non-proliferation Treaty (NPT), with which (1968) the international community established a significant norm in the nuclear field. The other important cornerstone is the le- gal and political possibility to create geographical areas free from nuclear weapons. The first territory to become a nuclear-weapons-free zone by the Tlateloco Treaty (1967) was Latin America and the Caribbean. It was followed by the Treaty of Raratonga in 1985 (the area of the South Pacific), the Treaty of Bangkok in 1995 (the area of South Asia), the Pelindaba Treaty in 1996 (Africa), and, finally, the Treaty of Semipalatinsk in 2008 (Central Asia). Un- inhabited areas such as the Antarctica (1959), outer space (1967) and the ocean floor (1971) were announced nuclear-weapons-free zones by the international community.

The initiative related to the Middle East also dates back to the 1960s. According to Mo- hamed Kadry Said ${ }^{3}$ Egypt suggested nine conditions for establishing a nuclear-weapon-free zone (NWFZ) in the Middle East in 1963, (Said, 2004: 126) on the basis of which in De- cember 1974 the creation of NFWZ in the Middle East appeared on the agenda of the United Nations for the first time. ${ }^{4}$ The antecedent of the proposal was the Arab Leage Summit on September 1-4, 1974 which took place after the end of the 1973-1974 Arab-Israeli war. The initiative was introduced at this summit, and was forwarded by Mohamed Reza Pahlavi,

1 National University of Public Service, Budapest, Hungary, nagymilada@ aposztrof.hu

2 chemical, biological, radiology, and nuclear weapons

3 Retired general, military and technology advisor of the Al-Ahram Center for Political and Strategic Studies (Cairo, Egypt) and head of military studies unit, member of the EuroMeSCo and the council of the Pugwash Organization for Science and World Affairs. He served in the Egyptian Armed Forces as air defense officer.

4 UN Assembly, Resolution 3263, 7 January 19 1975. Accepted with 128 yes, 0 no, 2 abstain (Israel, Mianmar)

NAGY Milada: International efforts to create a weapons of mass destruction free zone in the Middle East

the Shah of Iran, to the UN General Assembly on September 16, 1974, with the active support of Egypt. It was included in the proposal that "Middle Eastern states should be prohibited to manufacture or otherwise to acquire nuclear weapons," and countries possessing nuclear weapons should be prohibited to use weapons of mass destruction against the states of this area. The proposal urged the immediate establishment of safety measures related to nuclear and non-nuclear weapons, and Egypt established its right to take steps to preserve its own security iẩ 1 ase Israel possessed nuclear weapons. (Egypt State Information Service, s.1.)

Resolution 3263 of the UN General Assembly (1974) calls upon all parties concerned in the establishment of a nuclear-weapon-free zone in the region of the Middle East to refrain, on a reciprocal basis, from producing, testing, obtaining, acquiring or in any other way possessing nuclear weapons and to accede to the Nuclear Non-Proliferation Treaty. The resolution expresses hope that all states, including the nuclear-weapon states, will lend their full cooperation to the effective realisation of the aims of the resolution. According to the resolution the UN General Assembly annually discusses the issue and modifies it according to the current security policy situation. (UN, 1974:27)

In March 1975 the Secretary-General of the UN sent Resolution 3263 to the countries concerned for discussion. (UN, 1975) A nuclear-weapon-free zone in the Middle East would have been established by the accession of Bahrain, the United Arab Emirates, Egypt, Iran, Iraq, Israel, Yemen, Jordan, Qatar, Kuwait, Lebanon, Oman, Syria and Saudi Arabia (out of the listed countries Egypt is party to the Pelindaba Treaty, the Treaty of the African Nuclear- Weapon-Free Zone since 1996). The countries in their official answers referred to the diplo- matic difficulties. The question of Israel 
caused the strongest disagreement. Egypt and Iran were the countries which especially emphasized their distrust towards the Jewish state, this way obstructing the exposure of "mutual acceptance" which is related to the content of the resolution. The point upon which every Middle Eastern country - except for the country con- cerned - agreed was that one of the most important conditions of establishing a nuclear-weap- on-free zone was the accession of Israel to the Nuclear Non-Proliferation Treaty. (UN, 1975) Resolution 3263 of the UN General Assembly — pursuant to the content of the resolution - was modified every year according to the political and security situation. The states concerned continued to express their opinion and the UN Secretary General annually an- nounced them in his report. ${ }^{5}$ Bahrain, Egypt, Jordan, Kuwait, Lebanon and Oman supported the second paragraph of the resolution, which states that the parties refrain from producing, testing, obtaining, acquiring or in any other way possessing nuclear weapons. Egypt, Jordan, Iran, Iraq and Syria found it essential that all members of the area be members of the Nuclear Non-Proliferation Treaty (paragraph 3). Kuwait would ratify the Nuclear Non-Proliferation Treaty in case Israel did the same. According to Jordan, until Israel is not member of the NPT, the NWFZ cannot be realized. Israel stated that "it would take further steps in order to insure durable peace in the area", and was inclined to participate in the conferences dealing with the issue. (UN, 1975)

5 Resolutions of the UN General Assembly on the weapons of mass destruction free zones in the Middle East (1974-2012): 3263, 3474, 3171, 32/82, 33/64, 34/77, 35/147, 36/87, 37/75, 38/64, 39/54, 40/82, 41/48, 42/28, 43/665, 44/108, 45/52, 46/75, 47/48, 48/71, 49/71, 50/66, 51/41, 52/34, 53/74, 54/51, 55/30, 56/21, 57/55, $58 / 34,59 / 63,60 / 52,61 / 56,62 / 18,63 / 38,64 / 26,65 / 42,66 / 25,67 / 28$.

NAGY Milada: International efforts to create a weapons of mass destruction free zone in the Middle East

\section{The impact of the war between Iraq and Iran}

In the years after 1975 no serious changes took place. In 1980 the NWFZ resolutions were adopted without a vote because Israel gave up its abstention policy and participated in the sessions. In 1981 Israel bombed the Osiraq nuclear reactor in Iraq, claiming that this step had been a preventive attack concerning the security of the states of the region and its own security. The military action was condemned by the UN General Assembly in its Resolution

36/87, with particular regard to the forming of a nuclear-weapon-free zone in the Middle East. (UN, 1981:57) One year later, in 1982 the UN proposed in its Resolution 37/75 to take measures in order to prohibit the military attacks against nuclear instullations. (UN,

1982:56), (UN, 1983:57)

Meanwhile, during the war between Iraq and Iran (1980-1988) chemical weapons were used which caused the death of thousands of people, furthermore, it was revealed that some Middle Eastern countries were pursuing chemical and biological weapons programs (e.g. Syria). In reaction, in April 1990 the President of Egypt, Hosni Mubarak urged the creation of not just a nuclear-weapon-free zone, but that of a mass destruction weapons free zone in the Middle East (MEWMDFZ). He sent his proposal to the UN Secretary-General, the effect of which was that the UN General Assembly that year (1991) accepted Resolution 46/30 which "welcomes all initiatives leading to the general and complete disarmament, including in the region of the Middle East". (UN, 1991:61-62) Therefore, the significance of the creation of a weapons of mass destruction free zone in the Middle East was demonstrated at the level of both the UN Security Council and the General Assembly.

In 1991 UN Secretary-General, Javier Pérez de Cuéllar, (de Cuéllar 1991) presented a report on the same issue, the preparation of which was authorized by a 1981 Resolution of the UN General Assembly. (UN, 1991:61-62) The UN Secretary General defined the Middle East as a region spreading from Lebanon to Iraq, and from Syria to Yemen. He emphasized that Israel, according to its promise, "would not be the first to deploy nuclear weapons in the Middle East", 6 adding that from this statement it is not clear whether the testing of nu- clear weapons is included or not. The accession of the Middle Eastern states to the Nuclear Non-Proliferation Treaty — particularly that of Israel — as well as bringing Israel's nuclear research institute in Dimona ${ }^{7}$ under the control of the International Atomic Energy Agency (IAEA) would be an important step towards the realization of the goal. The study states that confidence-building measures similar to those taken in Europe after the end of the Cold War would be necessary in the region. (de Cuéllar 1991: 40-42)

\section{The 1990s}

After the first Gulf War (1991) the international community revealed the mass destruction weapons programs of Iraq, and the Security Council condemned the country's efforts of this kind in their Resolution 687 (April 13, 1991): “Iraq has attempted to acquire materials for 
7 A Nuclear Research Center operates in Dimona which has not been opened yet before the controllers of the IAEA.

NAGY Milada: International efforts to create a weapons of mass destruction free zone in the Middle East

a nuclear-weapons programme contrary to its obligations under the Nuclear Non-Prolifera- tions Treaty of 1 July 1968", and urged the creation of the nuclear-weapon-free zone in the Middle East. The Resolution obliged Iraq to destruct or remove all chemical and biological weapons and manufacturing facilities, to destruct all ballistic missiles with a range greater than 150 kilometres, this way creating a new proposal. The initial proposal, that is, the idea of nuclear-weaponfree zone was complemented, thus, the main goal of the new proposal was to create a weapons of mass destruction free zone in the Middle East. (UN Security Council [SC], 1991a)

At the beginning of the 1990s steps towards the disarmament of the Middle East took place not only in the UN. It was the Arms Control and Regional Security Working Group

- one of the five multilateral working groups formed within the framework of the Madrid Peace Process — where negotiations took place on the issue of creating a weapons of mass destruction free zone in the Middle East (May 1992-December 1994). Egypt and Israel held bilateral talks which ended with no practical results, due mainly to, on the one hand, the disagreement between the two parties concering the question of arms reduction (Egypt want- ed to expand the NPT to Israel), on the other hand, due to the end of the Arab-Israeli Peace Process. Although the series of negotiations brought no tangible results, the fact that Israel decided to discuss the question of arms reduction with its neighbours and other countries of the region was a positive result. Confidence-building became a significant concept and accompanied the Middle East peace negotiations in the 1990s.

\section{The Barcelona Process}

After the interruption of the Arab-Israeli Peace Process, the European Union also tried to interfere in the Middle East Peace Process. On November 27 and 28, 1995 at the Euro-Med- iterranean Conference in Barcelona the Barcelona Declaration was accepted, which stated that "the signatory parties ${ }^{8}$ shall pursue a mutually and effectively verifiable Middle East Zone free of weapons of mass destruction, [...] and their delivery systems", they should pro- mote regional security through non-proliferation regimes, that is, through arms control and disarmament agreements. ${ }^{9}$ Furthermore according to the Declaration - the parties will consider practical steps to prevent the proliferation of weapons of mass destruction as well as the excessive accumulation of conventional arms. In the last paragraph of the chapter on political and security partnership it was stated that the parties consider any confidence and se- curity-building measures that [...] contribute to the creation of an "area of peace and stability in the Mediterranean". (EU, 2005) The Euro-Mediterranean Partnership and the Barcelona Process supposed a dialogue and cooperation, but it was the key actors of the region (Israel, the Palestinian Authority, Egypt, Syria, Lebanon and Jordan) which did not agree with the cited points of the chapter on political and security partnership, therefore, the initial enthusi- asm started to decrease.

As a result of the revitalized initiative, on July 13, 2008 the Union for Mediterranean was established in Paris (UfM).

The closing declaration of the summit, similarly to the Barcelona

8 EU15 states, Egypt, Israel, Malta, the Palestinian Authority, Turkey, Tunisia, Syria, Jordan, Morocco, Lebanon, Algeria, Cyprus

9 Nuclear Non-Proliferation Treaty (NPT) 1968; Chemical Weapons Convention (CWC) 1993; Biological Weapons Convention (BWC) 1972; Comprehensive Test Ban Treaty (CTBT) 1996.

NAGY Milada: International efforts to create a weapons of mass destruction free zone in the Middle East

declaration, included a reference to the issue of the weapons of mass destruction free zone in the Middle East, but nonproliferation as a coneept was not included in it. (UN, 2008) The UfM was launched by Ex-President of France, Nicolas Sarkozy, though today it operates only at a formal level, and, regarding WMDFZ, it has brought no progress.

\section{An attempt to create the weapons of mass-destruction-free-zone of the Gulf States}

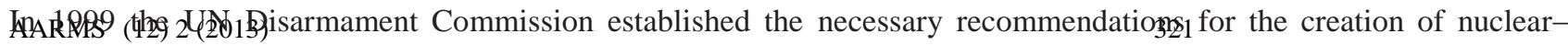
weapons-free zones. The basic criteria were that all the states of the zone had to accept the status, to insure efficient control and to urge the peacful use of nuclear energy. (Goldblat, 2005)

In December 2004 the initiative to create the NWFZ of the Gulf States, ${ }^{10}$ was put forward by the Gulf Research Center. However, it raised the question why the Arab Gulf States would want to have their own WMDFZ? The answer was obvious: it had been more than 40 years that the Middle East NWFZ was proposed and it had not been realized. Should a WMDFZ or a NWFZ be established in a territory much smaller than the originally foreseen scope, namely the Arab Gulf, it could expand into a NWFZ which covered the whole Middle East. Nevertheless, this aspiration has remained mostly academic thinking, consequently has not been realised yet. (Alani, 2005)

\section{The 1995 NPT Resolution}


The first reference to the creation of a NWFZ in the Middle East in the closure declarations of the NPT Review Conferences was mentioned in 1985, in points 11-13 of the VII paragraph: "The Conference welcomes the consensus [Resolution 39/54 - M. N.] reached by the Unit- ed Nations General Assembly concerning the establishment of a nuclear-weapon-free zone in the region of the Middle East." (Center for Nonproliferation Studies, 1985) Thereafter a further ten years passed before the question of WMDFZ in the Middle East appeared on the agenda. It was discussed at the NPT Review Conference held between April 17 and May12,

1995. The fact that the issue could appear on the agenda was due to the diplomatic efforts and the Arab-Israeli Peace Process, preceding the conference. Israel had been integrated into the NPT process, at bilateral levels, since 1994. Egypt had already expressed its opinion before, according to which if Israel signed the NPT, the Arab states would accede to the treaty on the prohibition of chemical weapons. The Arab League - under the leadership of Egypt - passed a resolution in their September 1994 session, proposing that all the states of the region should join the NPT, including Israel, but the Jewish state refused to join the treaty. By Janu- ary 1995, the rethorics of Egypt became harder. Amr Moussa, the Minister of Foreign Affairs accused Israel, saying that the secret weapon of mass destruction program of Israel was the reason why the Middle East Peace could not be realised. (Feldman, 1997)

In April-May 1995 Israel did not take part in the conference. Egypt decided that it would not support the "extension of the NPT without clarification" until Israel was not a party to the treaty. In addition, Egypt stated that if the majority of the NPT members voted for the

10 Bahrain, Oman, Kuwait, Saudi Arabia, Qatar, United Arab Emirates, Iraq, Iran and Yemen

NAGY Milada: International efforts to create a weapons of mass destruction free zone in the Middle East

extension of the treaty withouth naming Israel, it might make Egypt leave the NPT, and even undertake a potential confrontation with the USA. (Feldman, 1997) The Egyptian campaign did not manage to make Israel sign and ratify the NPT. As a result of the American pressure, the originally all-Arab position gradually disappeared and Egypt remained alone with its proposal. Eventually, the Resolution on the Middle East of the 1995 NPT Review Confer- ence contained no concrete reference either to the nuclear weapons of Israel, or to the arms reduction talks in the Peace Process. In the second point it "notes with satisfaction" that, in its report, the Main Committee of the Conference recommended to "call on those remaining States not parties to the Treaty to accede to it, and to accept International Atomic Energy Agency safeguards on all their nuclear activities". (UN, 1995) The last point (point 6) deals with safeguards. Its text is rather general, calling upon all states party to the Treaty on the Non-Proliferation of Nuclear Weapons, and in particular the nuclear-weapon states, to ex- tend their cooperation and to exert their efforts with a view to ensure the early establishment by regional parties of a Middle East zone free of all weapons of mass destruction. At the same time, it is important to mention that the integration of the MEWMDFZ into the NPT review process could not be successful until the parties have no confidence towards each other.

At the 2000 and 2005 NPT Review Conferences the 1995 resolution was confirmed, but the discussion of the issue took place only in May 2010, at the following review conference. The greatest result of the conference was that the participants accepted an action plan, con- sisting of 65 points, in order to realize the 1995 resolution, the NPT and the disarmament. Furthermore, another resolution was created about the organisation of a conference to be held in 2012 , counting on the participation of all the countries of the Middle East. After the conference, 28 May 2010 James L. Jones, National Security Advisor issued a declaration on behalf of the USA in which he confirmed his desire to be the co-sponsor of the 2012 conference (further sponsors are the United Kingdom, Russia and the Secretary General of the UN). Before the declaration Israel had strongly condemned the USA for voting for the resolution of the conference. The USA expressed the importance of the national security of Israel, and did not accept the isolation of Israel or the imposing of "impossible expectations". The USA states that its position concerning the Peace in the Middle East has not changed, including its "unwavering" commitment to the security of Israel. At the same time, they find it regrettable that Israel does not take part in that part of the NPT document which deals with the Middle East, and the fact that Iran regularly infringes the resolutions of the NPT and the UN SC. (Jones, 2010)

Finland was appointed to be the host of the conference, and Jaakko Laajava, the Finnish Under-Secretary of State became, later, its high representative. (UN SG [Secretary-Gener- al], 2012) The USA, Great Britain and Russia supported the initiative, but except for them - and the efforts of the Egyptian diplomacy - the European Union did not play a very active part. The EU similarly to the UN, supported the creation of the WMDFZ in the Middle East. In September 2008 the EU organised a seminar in Paris, as a result of which the European Council accepted the decision "in support of a process of confidence-building leading to the establishment of a weapons of mass destruction free zone and their means of delivery in the Middle East in support of the implementation of the EU Strategy against Proliferation of Weapons of Mass Destruction", and decided to organize another seminar.(EU, 2010) It took place on July 6-7, 2011, and was organized by the EU Non-Proliferation Consortium and was supported by the European External Action Service. The main points of the agenda,

NAGY Milada: International efforts to create a weapons of mass destruction free zone in the Middle East

similarly to those of the previous seminar, dealt with the possibilities of the creation of the confidence-building strategies and the MEWMDFZ. (EU, 2011a), (EU, 2011b) 
During the organisation process of the 2012 conference it became a widespread view that the conference was doomed to fail, and this would have a negative impact on the following five-year period (2010-2015) of the NPT Review Conferences. That time nobody supposed that the conference would not take place. As it came through the three main supporters (the USA, Great Britain and Russia) issued rather different declarations. On November 23, 2012 the US Department of State issued a declaration on the postponement of the conference, referring to the seriousness of the situation, ${ }^{11}$ but did not give any alternative date. One day later in the declaration of Russia the date of the conference was set for April 2013, empha- sizing that the preparations had reached the appropriate level, but some countries were not present, this was the reason why the conference did not take place. ${ }^{12}$ Great Britain, in its own declaration expressed its hope for the continuation of the dialogue and the organisation of the conference in 2013. (Davenport, 2012), (Landau, Stein, 2012) Until the inner conflicts of the region are not solved (Egypt as the main representative of the Arab world and Israel are not able to bring their ideological points of view in line with one another; Israel, for safety rea- sons, would not discuss giving up its available weapons; Iran continues its nuclear program

— though the international community has serious doubts as to its being for peaceful pur- poses; — in Syria due to the civil war the situation of the chemical and biological weapons cannot be arranged ${ }^{13}$ etc.), no conference will be able to realise a WMDFZ in the Middle East.

\section{Conclusion}

The Iran-Iraq war, the first Gulf War and the situation of nuclear non-proliferation in the region all had and still have a great impact on the development of the WMDFZ initiative. Several other factors could interrupt the process (for instance, a deterioration in the settle- ment of the Israeli-Palestinian relations) which is closely connected with the development of the security and diplomatic situation of the region.

The postponement of the 2012 conference seems to mark a deadlock in the process, since the participants firmly insist on their viewpoints. The obstinacy can also be explained by the multilateral diplomacy, as it excludes the possibility of real dialogue between the parties. As it was written in the declaration of the US: "Outside states cannot impose a process on the region [...]. The mandate for a MEWMDFZ must come from the region itself. A compre- hensive and durable peace in the region and full compliance by all regional states with their arms control and nonproliferation obligations are essential precursors for the establishment of such a zone". (Nuland, 2012)

11 The Operation Pillar of Defense was an Israel Defence Forces operation against the Gaza Strip which started November 14, 2012 and ended November 21, 2012.

12 Israel indicated that its country would not participate in the conference. Iran had stated earlier that it is unwilling to have any kind of talk with Israel, and refused to go to Helsinki, but after hearing that Israel would not take part in it, accepted the invitation. According to analysts Iran did it only when it became obvious that the conference would be cancelled.

13 On September 14, 2013 an agreement was reached between US Secretary of State John Kerry and Russian Foreign Minister Sergey Lavrov on Syria's chemical weapons. The purpose is the total destruction of Syria's chemical capability. Untill now (September 21, 2013) there is no concrete scenario about its implementation.

NAGY Milada: International efforts to create a weapons of mass destruction free zone in the Middle East

\section{References}

ALANI, M. (2005): The Case for a Gulf Weapons of Mass Destruction Free Zone, http://www.grc.net/bulletin_WMD_Free_Zone.pdf. (downloaded: 1404 2013)

COMPREHENSIVE TEST BAN TREATY (1996): http://www.ctbto.org/the-treaty/ (downloaded: 1404 2013)

DAVENPORT, K. (2012): WMD-Free Middle East Proposal at a Glance. http://www.armscontrol.org/factsheets/mewmdfz (downloaded: 2405 2013)

de CUÉLLAR, J. P. (1991): Study on Effective and Verifiable Measures which Would Facilitate the Establishment of a Nuclear Weapons Free Zone in the Middle East. http://www.un.org/ disarmament/HomePage/ODAPublications/DisarmamentStudySeries/PDF/SS-22.pdf (downloaded: 1404 2013)

AARGS (F STATEINFORMATION SERVICE (s.1.): Egypt and weapons of mass destruction in the Middle East.http://www.sis.gov.eg/en/LastPage.aspx?Category_ID=65. (downloaded: 1404 2013)

EU (2005): Barcelona Declaration. http://trade.ec.europa.eu/doclib/docs/2005/july/ tradoc_124236.pdf(downloaded: 1404 2013)

EU (2008): Union for Mediterranean — Declaration. http://ufmsecretariat.org/wp-content/ uploads/2012/09/ufm_paris_declaration1.pdf (downloaded: 2404 2013)

EU (2010): Council Decision 2010/799/CFSP of 13 December 2010 in support of a process of confidence-building leading to the establishment of a zone free of weapons of mass destruction and their means of delivery in the Middle East in support of the implementation of the EU Strategy against Proliferation of Weapons of Mass Destruction. http://eur-lex.europa. eu/LexUriServ/LexUriServ.do?uri=OJ:L:2010:341:0027:0031:EN:PDF (downloaded: 1404 2013)

EU (2011a): Articles of EU Non-Proliferation Consortium. http://www.cesim.fr/observatoire/ eng/69/article/19 (downloaded: 2405 2013)

EU (2011b): EU Seminar to promote confidence building and in support of a process aimed at establishing a zone free of WMD 
and means of delivery in the Middle East; Final assesment of the Seminar of EU Non-Proliferation Consortium (6-7. 07. 2011). http://www.nonproliferation.eu/documents/final_assessment.pdf (downloaded: 2405 2013)

FELDMAN, S. (1997): Nuclear Weapons and Arms Control in the Middle East. Cambridge: Harvard University, ISBN 0$262-56108-5$

GOLDBLAT, J (2005): Why is the GWMDFZ Project Important? http://www.isn.ethz.ch/Digital-Library/Publications/Detail/?ots591=0c54e3b3-1e9c-be1e2c24-a6a8c7060233\&lng=en\&id=56123 (downloaded: 1406 2013)

JONES, J. L. (2010): Statement by the National Security Advisor, General James L. Jones, on the Non-Proliferation Treaty Review Conference. http://www.whitehouse.gov/the-press- office/statement-national-security-advisor-general-james-1jones-non-proliferation-treaty- (downloaded: 1504 2013)

LANDAU, E. B., STEIN, S. (2012): The Decision to Call Off the 2012 WMDFZ Conference: An Outcome Destined from the Start? INSS Insight, No. 390, 05122012.

MIIS CENTER FOR NONPROLIFERATION STUDIES (1985): Final declaration of NPT review conference, (27. 08.-21. 09. 1985). http://cns.miis.edu/inventory/pdfs/NPTRevCon85.pdf (downloaded: 2404 2013)

NULAND, V. (2012): 2012 Conference on a Middle East Zone Free of Weapons of Mass Destruction (MEWMDFZ), Declaration of USA Department of States, Washington, DC, 2311 2012 http://www.state.gov/r/pa/prs/ps/2012/11/200987.htm (downloaded: 1404 2013)

NAGY Milada: International efforts to create a weapons of mass destruction free zone in the Middle East

SAID, M. K. (2004): Middle East Weapons of Mass Destruction Free Zone: Regional Security and Non-Proliferation Issues. In. Building a Weapons of Mass Destruction Free Zone in the Middle East. Global Non-Proliferation Regimes and Regional Experiences, UN, Geneva, pp.

123-133. ISBN 92-9045-168-8 or http://www.unidir.org/files/publications/pdfs/building-a- weapons-of-massdestruction-free-zone-in-the-middle-east-global-non-proliferation-regimes- and-regional-experiences-321.pdf (downloaded: 2404 2013)

THE BIOLOGICAL WEAPONS CONVENTION (1972): http://www.opbw.org/ (downloaded: 1404 2013)

THE CHEMICAL WEAPONS CONVENTION (1993): http://www.opcw.org/chemical-weapons- convention/ (downloaded: 1404 2013)

THE NUCLEAR NON-PROLIFERATION TREATY (1968): http://www.un.org/en/conf/ npt/2005/npttreaty.html (downloaded: 1404 2013)

THE NUCLEAR THREAT INITIATIVE (2013): Nuclear. http://www.nti.org/country-profiles/ israel/nuclear/ (downloaded: 1405 2013)

UN (1995): Resolution 32/1995 of NPT review conference. http://www.un.org/disarmament/WMD/Nuclear/1995NPT/pdf/Resolution_MiddleEast.pdf (downloaded: 2404 2013)

$\mathrm{UN}$ (s.1.): UN General Assembly resolutions accoeding to MEWMDFZ. http://www.un.org/depts/dhl/resguide/gares1.htm (downloaded: 1404 2013)

UN ASSEMBLY (1974): 3263 (XXIX). Establishment of a nuclear-weapon-free zone in the region of the Middle East. http://www.un.org/ga/search/view_doc.asp?symbol=A/ RES/3263\%28XXIX\%29\&Lang=E\&Area=RESOLUTION (downloaded: 2404 2013)

UN ASSEMBLY (1975): Establishment of a nuclear-weapon-free zone in the region of the Middle East S/11778, Add. 1, Add. 2, Add. 3, Add. 4. https://disarmamentlibrary.un.org/UNODA/Library.nsf/9c58922852b2d6d88525757d004f36df/ aca81c923caf41d8852578ae0065357b?OpenDocument (downloaded: 2803 2013)

UN ASSEMBLY (1981): 36/87 Establishment of a nuclear-weapon-free zone in the region of the Middle East. http://www.un.org/ga/search/view_doc.asp?symbol=A/ RES/36/87\&Lang=E\&Area=RESOLUTION (downloaded: 1404 2013)

UN ASSEMBLY (1982): 37/75 Establishment of a nuclear-weapon-free zone in the region of the Middle East. http://www.un.org/ga/search/view_doc.asp?symbol=A/ RES/37/75\&Lang=E\&Area=RESOLUTION (downloaded: 1404 2013)

UN ASSEMBLY (1983): 38/64 Establishment of a nuclear-weapon-free zone in the region of the Middle East. http://www.un.org/ga/search/view_doc.asp?symbol=A/ RES/38/64\&Lang=E\&Area=RESOLUTION (downloaded: 1404 2013)

UN ASSEMBLY (1991): 46/30 Establishment of a nuclear-weapon-free zone in the region of the Middle East. http://www.un.org/ga/search/view_doc.asp?symbol=A/ RES/46/30\&Lang=E\&Area=RESOLUTION (downloaded: 1704 2013)

UN SC (1975): UN SC resolution 11778. https://disarmamentlibrary. un.org/UNODA/Library.nsf/9c58922852b2d6d88525757d004f36dff 7 aca81c923caf41d8852578ae0065357b? OpenDocument (downloaded: 1404 2013)

UN SC (1991-1994): UN SC resolution 715. http://www.un.org/Depts/unscom/Chronology/ resolution715.htm (downloaded: 2803 2013)

UN SC (1991a): UN SC resolution 687. http://www.un.org/Depts/unscom/Chronology/ resolution687.htm (downloaded: 2803 2013)

UN SC (1991b): UN SC resolution 707. http://www.un.org/Depts/unscom/Chronology/ resolution707.htm (downloaded: 2803 2013)

UN SG (2012): Finland Appointed as Host Government, Facilitator for 2012 Conference on Middle East as Zone Free of Nuclear, All Mass-Destruction Weapons. http://www.un.org/ News/Press/docs/2011/sg2180.doc.htm (downloaded: 2404 2013) 